調査報告

\title{
南海トラフ地震による大分県佐伯市と 番匠川河川環境の被害想定
}

東野 誠* ·鬼束幸樹** ·横田恭平* 古川隼士* $\cdot$ 熊沢大地 ${ }^{* * *}$

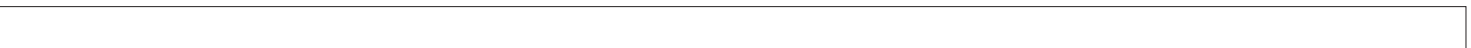

要旨

本研究では, 大分県佐伯市を対象として津波防災について検討を行うとともに，番匠川河川環境の津波に よる被害想定を行った，佐伯市は，南海トラフ地震発生時には県内で最も早く津波が到達するとともに，場 所によっては予想される津波高は $10 \mathrm{~m}$ を超える，検討にあたっては，中央防災会議が実施した津波の佐伯市 街地への津波到達時間, 浸水深, および氾濫流速を基に, 現況での津波防災と番匠川河川環境や生態系への 影響を考察した。

キーワード : 津波, 防災対策, 南海トラフ地震, 佐伯, 番匠川
\end{abstract}

\section{1.まえがき}

東北地方太平洋沖地震（2011年 3 月11日）とそれに 伴う津波は, 東北地方の太平洋沿岸部に壊滅的な被害 をもたらした。これを受けて中央防災会議では, 南海 トラフ巨大地震について, 想定される最大クラスの地 震，津波に対して被害の想定の見直しが行われた ${ }^{1)}$. 大分県においても, 県内市町村のハザードマップ作成 に資することを目的に南海トラフ, 別府湾, 周防灘を 震源とする 3 地震についてシミュレーションを行い, 県内 43 地点の津波の高さや到達時間を算出して, これ らに基づいた防災対策が検討されている ${ }^{2)}$.

従来, 洪水汇濫災害に関して, 多くの検討が行われ てきた. 須賀 ${ }^{3)}$ は江戸時代の大井川渡渉則を取り上げ, 流水中の水中歩行について広い範囲の条件のもとで 行った実験結果を加味して整理し直し, 水中歩行限界 や安全条件の一般化を図った，洪水ハザードマップを 作成するためには, 複雑な場における汇濫水の挙動を 正確に表せるモデルが不可欠である。中川ら ${ }^{4)}$ は, 都市域に打ける洪水の挙動に関して大規模な水理模型
実験を行い，実験結果に基づいて数值解析モデルの適 用性について検討した。 その際, 地上での汇濫のみな らず，地下空間への浸水についても考案している. 1999年, 2003年の福岡水害, 2000年の東海水害に見ら れるように都市域の洪水汇濫は地下空間への浸水とい う危険性を有している。地下空間に扔ける氾濫水の挙 動を知ることは防災面でも重要であり, 研究が進めら れてきたが, 避難の際の階段部等の局所的な状況まで は適切に表現されていなかった。 戸田ら ${ }^{5)}$ は, 実際 の地下街を再現した模型による水理実験から浸水過程 を明らかにし, 得られた実験結果から数值解析モデル を検証した。また, 地下からの避難の困難性, 浸水時 の危険性について考察している. 近年, 集中的降雨の 増加に伴い, 下水道が整備された地域においても都市 型水害が頻発する事態になっている。 これに対して, 黄ら ${ }^{6)}$ は, “水のみち”の構築による水害軽減という 新しい減災技術開発を試みた。これは, 道路や建築物 等の再配置により，洪水の流れを公園や農業地等に誘 導して市街地の浸水深を抑えるものである。また, 石 垣 $~^{7)}$ は, 地下空間の避難困難度に関する定量的な 
評価を実物大の階段やドアを用いて，地下から地上ま での避難を想定して実施した，都市部では，積極的に 地下空間の利用が図られているが，ヒートアイランド 化の進行に伴って局所的集中豪雨が頻繁に発生してい る昨今, 地下空間の浸水被害が増大している. 原田ら ${ }^{8}$ は，実スケールの地下街における浸水時の群衆避難の シミュレーションに対するモデルの適用性を明らかに するために，実在地下街の店舗隔壁，通路，広場等の レイアウトの詳細を考慮した境界条件下で，複数の浸 水シナリオを想定して，避難シミュレーションを実施 した，以上のように，洪水汇濫に関する検討例は枚挙 に睱がないが，これらは集中豪雨等を想定したもので あり，津波による洪水を想定したものではない．

本研究は, 南海卜ラフ地震を想定し, 大分県佐伯市 を対象に津波防災刘策について検討を行ったものであ る。 大分県佐伯市は，南海トラフ地震発生時には県内 で最も早く津波が到達する，加えて，場所によっては 予想される津波高は $10 \mathrm{~m}$ を超える. 検討にあたっては, 現地踏査を行い佐伯市街地の現況を把握するととも に, 佐伯市が指定している津波緊急避難施設を調べた。 これら，㧍よび中央防災会議による南海トラフ地震に 起因する津波の佐伯市街地への到達時間，浸水深，汇 濫流速から，現況での津波防災について検討した。 た，津波が番匠川の河川環境や生態系に及ぼす影響を 考察した。

\section{2. 調査対象地域}

検討対象とした佐伯市は大分県の南東端に位置し
（図 1 ),面積 $903.53 \mathrm{~km}$ ，人口約 75,000 人であり，その大 部分は番匠川河口の佐伯湾沿いの市街地に集中する。 中央防災会議や大分県の検討では南海トラフ地震発生 後, 約50分で $5 \sim 7 \mathrm{~m}$ の津波が到達すると予測されて いる ${ }^{1,2)}$ 。しかし，佐伯湾にはこのような津波から市 街地を守るための防波堤は設置されていない。した がって，ハザードマップ等による地域住民への避難方 法の周知徹底や防災に対する意識の向上等のソフト面 での対策が必要である。また,市街地には番匠川, およ びその派川の中江川, 中川等が貫流しており（図２）, それらの河川を津波が遡上し, 津波被害が佐伯湾沿岸 のみならず内陸部まで拡大することが懸念される。

な扮，上述の番匠川は，大分県佐伯市三国峠を水源 とする幹線流路延長 $38 \mathrm{~km}$ ，流域面積 $464 \mathrm{~km}^{2} の 一$ 級河川 であり，豊かな自然環境と生態系を有することが知ら れている.すなわち，上流の山間部ではゲンジボタル， カワセミ，ヤマセミが生息する。一方，下流の水際に はヨシ群落が点在し，オオヨシキリ等のハビタットと なっている．河口干潟は河口沖と河口端から約 $2.5 \mathrm{~km}$ 上流までの左岸側に形成されており，面積は約30ha である。この干潟にはハマボウ群落が分布し，水面に はマガモ，ヒドリガモ，カワウ等が生息している。 ま た，干潟はアサリやハマグリの漁場でもある ${ }^{9)}$.

\section{3 ．津波遡上・浸水予測結果}

南海トラフ巨大地震による津波が佐伯湾，そして市 街地へと来襲することを想定して，佐伯市街地での地 震発生時から津波が到達するまでの時間，浸水深，お

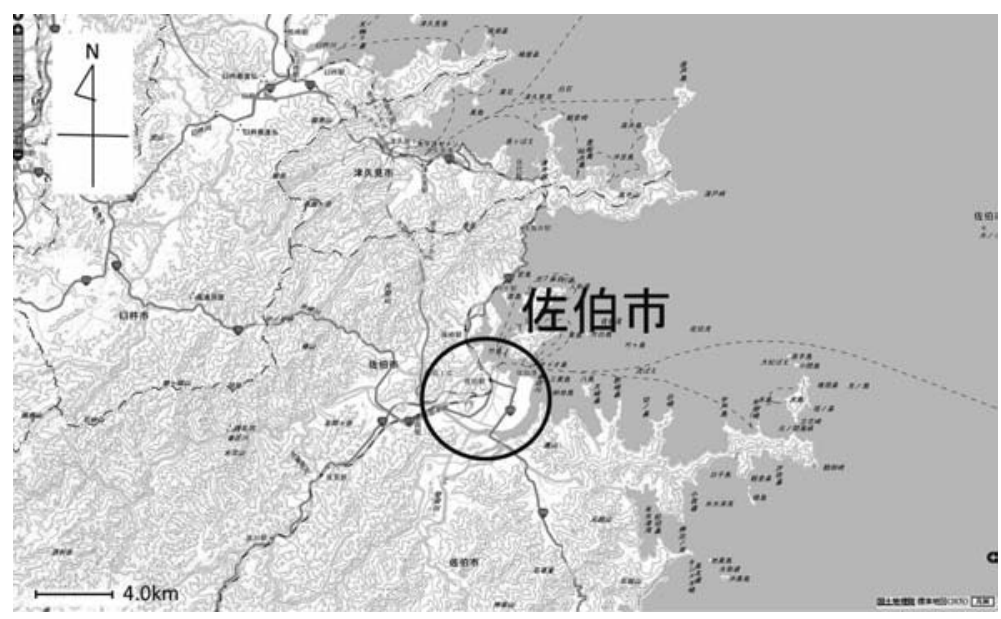

図 1 検討対象地域（大分県佐伯市） 
よび氾濫流速について, 中央防災会議（2012年）によ る検討結果を図 $3 \sim 5$ に示す。検討では, 最大クラス の津波（L2津波）が想定され，南海トラフで発生し 得る巨大地震の津波断層モデルが用いられた。このよ うな津波を伴う地震の発生間隔は300～500年とされて いる1).
図 3 より, 中川河口付近の最大浸水深は $5 \mathrm{~m}$ 以上で あるが，内陸部へと入り込むほど低下する様子が見て 取れる。また，佐伯市街地の大部分で浸水深は $2 \mathrm{~m}$ を 超える. 図 4 は津波到達時間の検討結果を示したもの である。な拉， $30 \mathrm{~cm}$ 以上の水位の上昇が津波の到達と されている。この図より，津波は発震後40～50分で海

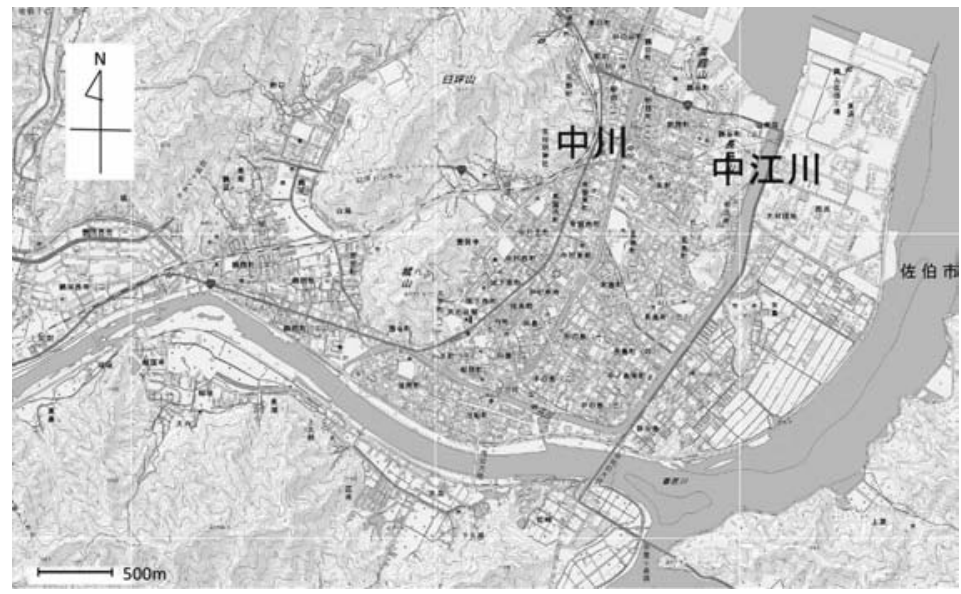

図 2 佐伯市街地

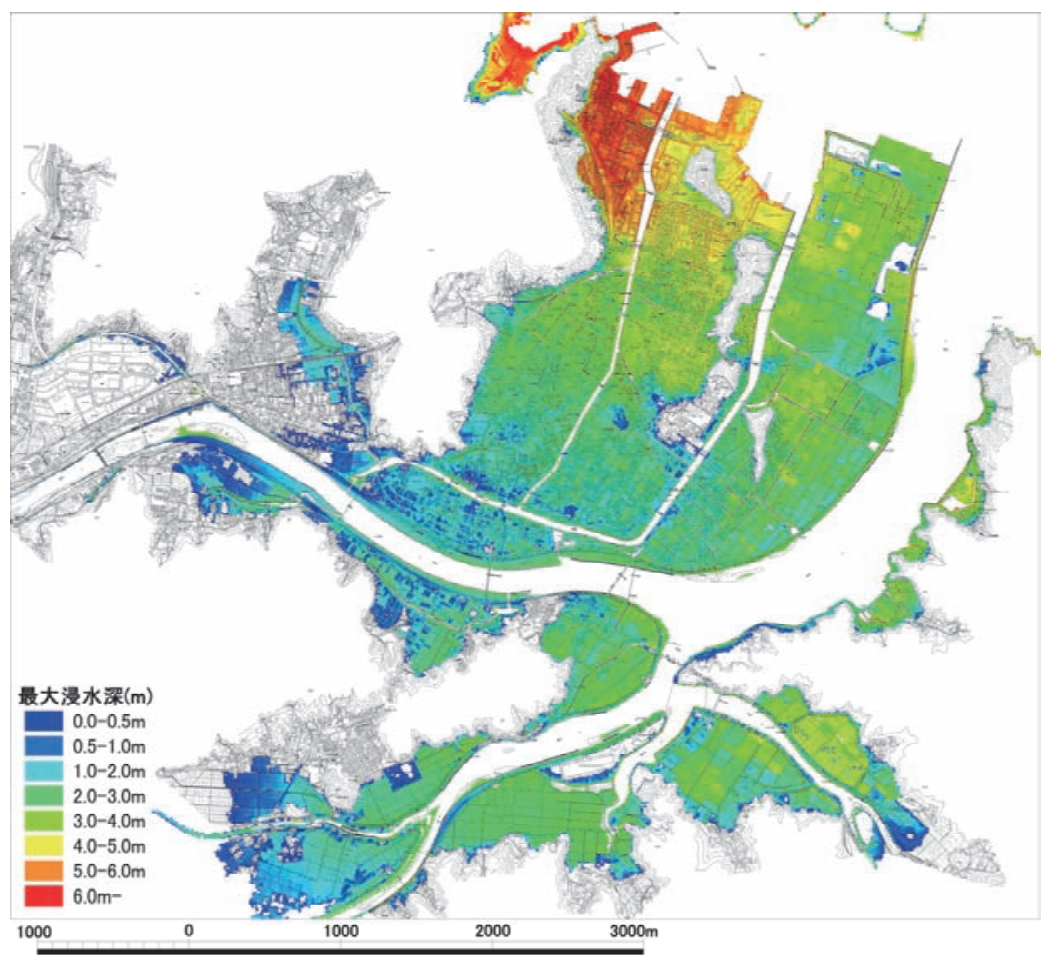

図 3 南海トラフ地震津波による最大浸水深 


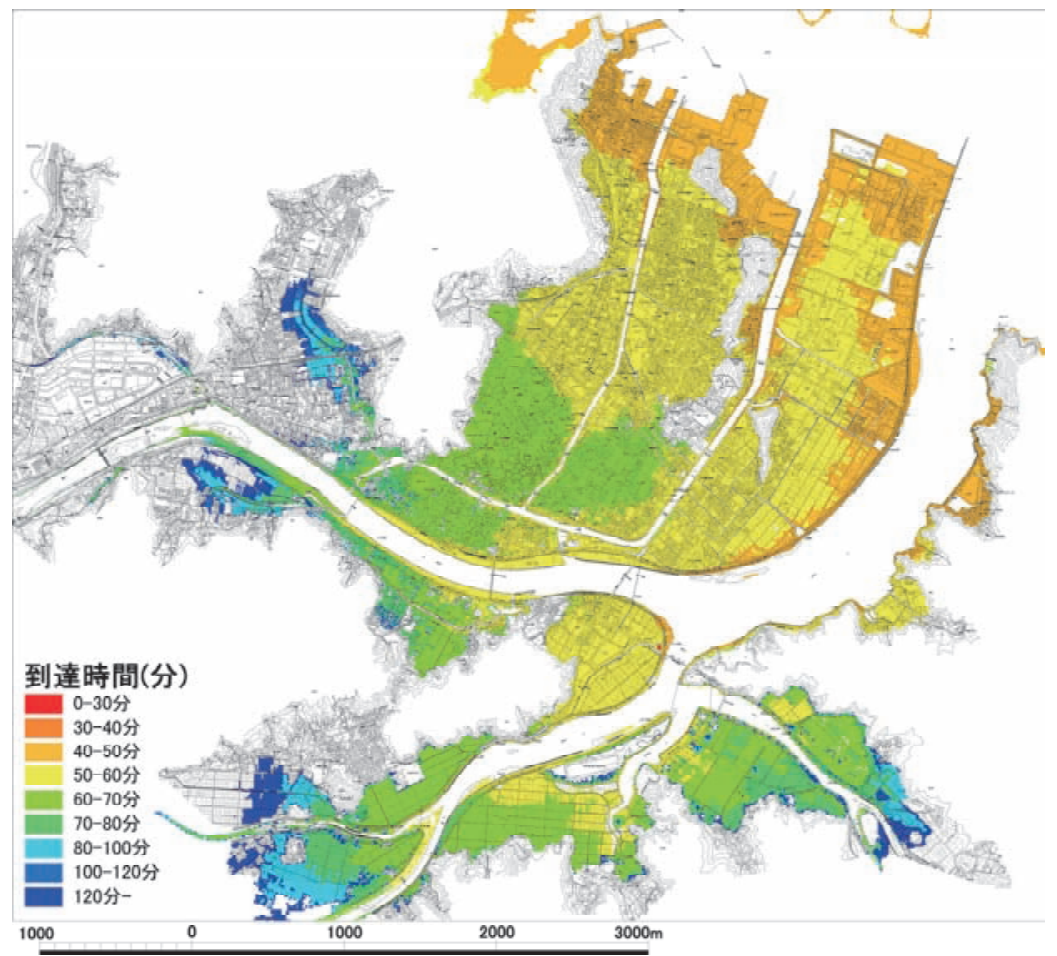

図 4 南海トラフ地震津波の到達時間

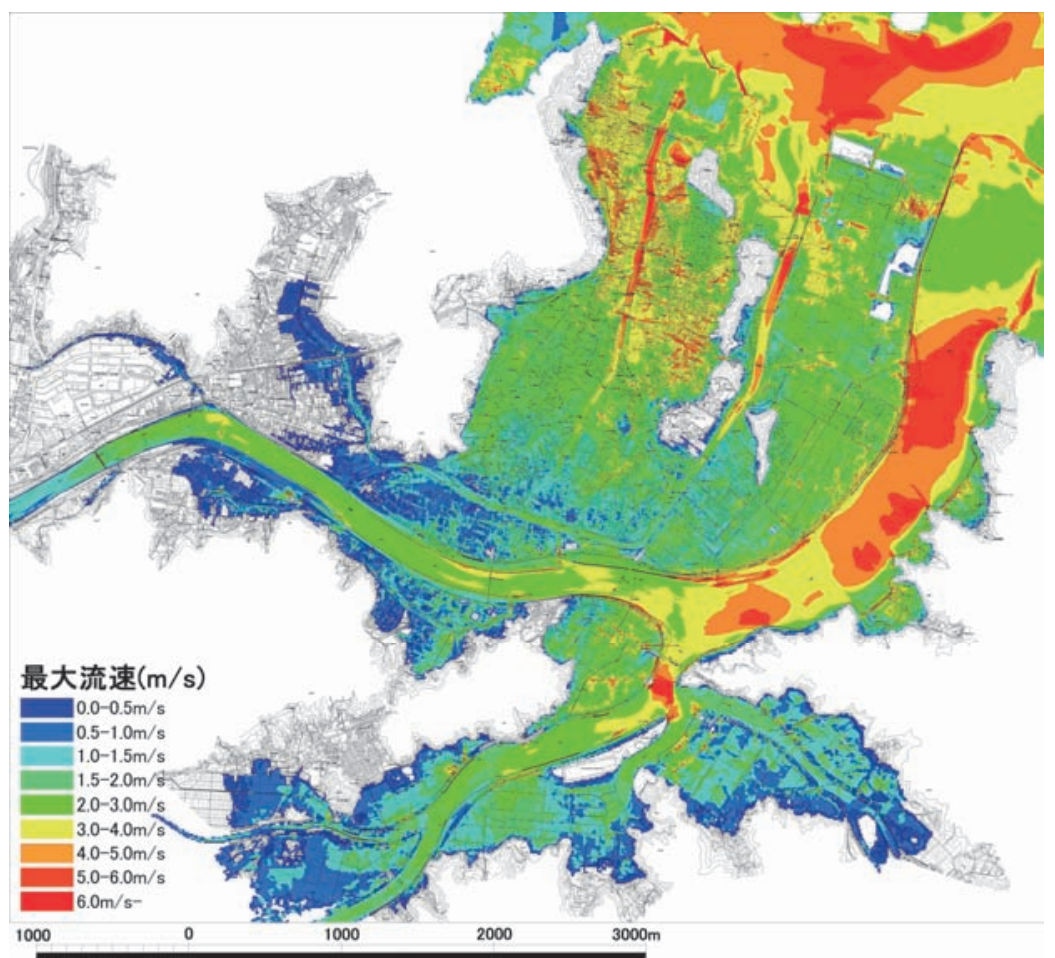

図 5 南海トラフ地震津波による氾濫流速 
岸部に到達する。佐伯市街地で海岸に近い部分では約 60分, 海岸から内陸部へと入り 込み, 堅田川との合流 点よりも上流側の番匠川に沿った地域では60～90分と なっている，図 5 より，佐伯市街地の大部分では津波 による汇濫流速は $3.0 \mathrm{~m} / \mathrm{s} に$ 達するか, それ以上となる。 また，番匠川，中川，中江川に抢いては，場所によっ ては $5.0 \mathrm{~m} / \mathrm{s}$ 以上となる。前述（2.）のように津波が これらの河川を遡上する様子が見て取れる。

\section{4 . 津波避難計画}

\section{1 緊急避難候補施設の選定}

$10 \mathrm{~m}$ 超えるような南海トラフ地震による津波を想 定して，佐伯市では市街地を対象に総合庁舎，高層住 宅，小・中学校，ホテル，公民館，病院等36の建築物 を緊急避難場所として設定している(表 1 )。これら の建築物は鉄筋または鉄骨鉄筋コンクリート造であ り，新耐震基準（1981年施工）が適用されている。す なわち, 緊急避難施設は想定される地震に耐え得るも のが選定されている。また，これらはいずれも $10 \mathrm{~m}$ 以 上であり，想定される最大の津波よりも高い。ここで は，地震発生時の津波に対する緊急避難について以下 に考察する。

\section{2 避難可能範囲}

地震発生時の緊急避難可能範囲に関しては，次のよ うに考えた。まず，発震の後，避難行動を開始するま でに要する時間を20分とした，津波は発震後，地区に よっては最短40分で到達する.前述（3.）のように水 深 $30 \mathrm{~cm}$ を津波の到達としているが, 既往の研究結果 ${ }^{3)}$, および高齢者や身障者を想起すれば， $30 \mathrm{~cm}$ 以上の水深 では歩行は困難であると推察される。したがって，残 された20分が避難のための時間となる．歩行による避 難の場合，その速度は成人で約 $4 \mathrm{~km} /$ 時 (約 $67 \mathrm{~m} /$ 分) であるので, $67 \mathrm{~m} /$ 分 $\times 20$ 分 $\fallingdotseq 1,300 \mathrm{~m}$ を地震・津波 時の歩行による避難可能距離と考えることができる. 図 6 (48頁) は各々の避難場所を中心とした半径1,300 $\mathrm{m}$ の領域を避難可能範囲として示したものである。こ の図より, 市街地の大部分（9 割以上）が避難可能範 囲であるのがわかる.

上述の検討は, 避難者が最寄りの緊急避難施設を把 握したうえで迅速に最短距離で避難することを想定し ている。最寄りの緊急避難施設を正確に把握していな かったり，地形や道路の線形等によって実際には避難 可能距離は上述の検討例よりも短くなると考えられ

\section{表 1 緊急避難候補施設}

\begin{tabular}{|c|c|c|}
\hline No & 場所 · 施設名 & 収容人数 \\
\hline 1 & ホテルニュー佐伯 & 830 \\
\hline 2 & ホテル富杵荘 & 45 \\
\hline 3 & 山城家 本館 & 220 \\
\hline 4 & 山城家 新館 & 150 \\
\hline 5 & 西島ビル & 80 \\
\hline 6 & 桧垣ビル & 280 \\
\hline 7 & (株) 大分銀行佐伯池船町社宅 & 44 \\
\hline 8 & リバーサイド池船 & 25 \\
\hline 9 & 佐伯城南中学校 & 690 \\
\hline 10 & 渡町台小学校 & 5,570 \\
\hline 11 & 大分県佐伯総合庁舎 & 470 \\
\hline 12 & 海上自衛隊佐伯基地分遣隊本部庁舎 & 930 \\
\hline 13 & 大分県立佐伯鶴城高等学校 & 1,000 \\
\hline 14 & ニュースター春日 & 100 \\
\hline 15 & ホテル金水苑 本館 & 140 \\
\hline 16 & ホテル金水苑 新館 & 490 \\
\hline 17 & サンビュー南海 & 100 \\
\hline 18 & 佐伯中央病院 & 100 \\
\hline 19 & 佐伯東小学校 & 610 \\
\hline 20 & 第一交通ビル & 420 \\
\hline 21 & まな美 & 260 \\
\hline 22 & シャングリラ佐伯 & 370 \\
\hline 23 & 市営野口団地 & 1,482 \\
\hline 24 & 鶴岡地区公民館 & 260 \\
\hline 25 & 長門記念病院 & 800 \\
\hline 26 & 鶴岡小学校 & 730 \\
\hline 27 & 上岡第 1 浄水場 & 25 \\
\hline 28 & 西田病院 & 1,250 \\
\hline 29 & 佐伯市消防本部 & 800 \\
\hline 30 & 慶’s コスモタワービル & 280 \\
\hline 31 & 市営城西団地 $\mathrm{A}$ 棟 & 1,275 \\
\hline 32 & 市営城西団地 B 棟 & 828 \\
\hline 33 & 市営城西団地 C 棟 & 733 \\
\hline 34 & 下堅田小学校 & 430 \\
\hline 35 & 市営熟谷住宅 & 294 \\
\hline 36 & 西浦小学校 & 490 \\
\hline
\end{tabular}

る。そこで，半径を図 6 の1/2の $650 \mathrm{~m}$ として同様の検 討を行えば，図７（48頁）のようである。これより中 川，および中江川は河口付近から内陸部まで川沿いに 緊急避難施設が存在し, 市街地の $6 \sim 7$ 割は避難可能 範囲となっている。一方，中江川と番匠川に囲まれた 地区は緊急避難施設が十分ではない。これらの地区で 
は，40〜50分と, 発震後, 比較的短時間で津波が到達 すること，扔よび地震によって橋が崩壊すれば周囲か ら孤立する可能性があることを考えれば，早急に何ら かの対策を講じる必要があることが示唆される.

\section{3 問題点と今後の課題}

今回の検討では, 各緊急避難場所・施設の中心から 半径 $1,300 \mathrm{~m}$, および $650 \mathrm{~m}$ 以内を避難可能範囲とした. しかしこれらは，前述（4.2）のように高齢者や身障 者等を考慮すれば, 適正であるとは言い難い。これは, 高齢者や身障者が避難場所・施設に避難する際，一般 的に避難により多くの時間を要することに加えて, 避 難経路に手すりがついた階段やエレベーターが設置さ れているといった高齢者に配慮されている限られた場 所・施設にしか避難できないからである，また，浸水 によってエレベーターの使用が困難な場合も想定さ れ，高齢者や障害者に対しても，安全かつ迅速に避難 が可能な避難計画を検討していく必要がある。また， 佐伯市が指定した各施設の収容人数の総数は約 23,000 人であり，佐伯市の人口75,000人全員の避難が可能な 施設・場所を確保できていない，今後は，さらなる緊 急避難施設の確保，またそれらのエレベーターや階段 の数と規模，さらには，佐伯市街地での人口の分布等 をも考慮に入れてより詳細な検討が必要である。

\section{5．環境や生態系への影響}

前述（4．）の議論は，想定される津波に対して新 たな築堤等のハード的な対策を講じない場合を想定し ている. 同様の条件で，津波が番匠川の河川環境と生 態系に及ぼす影響について以下に考察する。まず，河 口干潟では，八マボウ群落やアサリ，ハマグリは津波 によって壊滅的な被害を受け，干潟での生態系が劣化 すると考えられる，反面，番匠川河口干潟でのアサリ 生態に関する既往の研究 ${ }^{9)}$ では，干潟に堆積した底 泥による底質環境の悪化が当該水域でのアサリやハマ グリの個体数が減少の一因であることが指摘されてい る。図 5 に示すように $5 \mathrm{~m} / \mathrm{s}$ を超えるような津波に よる流れが底泥を取り除き，環境改善に繋がる可能性 もある，次に，津波が河口より約 $7 \mathrm{~km}$ 程度上流まで遡 上することが予想されるため，ヨシ群落やそこに生息 するオオヨシキリ等にも甚大な影響を及ぼすことが懸 念される.

以上のように，現況の状態で特にハード面での対策を 講じなければ，津波は番匠川河川環境と生態系に甚大
な影響を及ぼすと予想され，今後の検討が必要である。

\section{6. 結 論}

本研究では, 南海トラフ巨大地震を想定して, 大分 県県南の佐伯市を対象として津波防災について検討し た。結果を要約すれば，以下のようである。

1）佐伯市による緊急避難施設 36 力所について，これ らの中心から半径 $1,300 \mathrm{~m}$, および650mを避難可能範 囲として検討を行った。半径 $1,300 \mathrm{~m}$ とすれば，佐伯 市街地の約 9 割が避難可能範囲となる。一方, 半径 650mでは, 市街地の 6 ～ 7 割は避難可能範囲となる が，地区によっては緊急避難施設が十分ではなく，孤 立する可能性がある.

2 ) 佐伯市が指定した各施設の収容人数の総数は約 23,000 人であり，人口 75,000 人全員の避難が可能な施 設・場所を確保できていない，今後は，さらなる緊急 避難施設の確保，また，それらのエレベーターや階段 の数と規模, さらには, 佐伯市街地での人口の分布等 をも考慮に入れてより詳細な検討が必要である.

3 ) 番匠川では，現況の状態で特にハード面での対策 を講じなければ，河口干潟のハマボウ群落は津波に よって壊滅的な被害を受ける。津波が河口より約 $7 \mathrm{~km}$ 程度上流まで遡上することが予想されるため，ヨシ群 落やそこに生息するオオヨシキリ等にも甚大な影響を 及ぼす。

謝辞：本研究は，河川技術研究開発制度 地域課題分 野公募（河川）「東南海地震による津波を想定した大 分県番匠川流域の地域住民との合意形成に基づく防災 対策の提案」(代表：東野誠）の援助を受けて行わ れた。ここに記して，謝意を表する。

\section{参考文献}

1 ) 中央防災会議; 南海トラフ巨大地震の被害想定について (第一次報告)，(平成24年 8 月 24 日），2012.

2 ) 大分県；大分県津波浸水予測調査浸水予測図（速報版）, (平成24年11月28日)，2012.

3 ) 須賀如川; 水中歩行限界と避難・救助法に関する考察, 土木学会水工学論文集，46，839-844, 2002.

4 ) 中川一, 石垣泰輔, 武藤裕則, 八木博嗣, 張浩; 都市域 を対象とした洪水汇濫模型実験と解析，土木学会水工学 論文集，48, 571-576, 2004.

5 ) 戸田圭一, 井上和也, 大八木亮, 中井勉, 竹村典久 ; 複 雑な地下空間の浸水実験，土木学会水工学論文集，48, 583-588, 2004.

6 ）黄光偉, 磯部雅彦; “水のみち”による都市域水害軽減の 提案，土木学会水工学論文集，50, 571-576, 2006.

7 ) 石垣泰輔, 戸田圭一, 馬場康之, 井上和也, 中川一; 実 物大模型を用いた地下空間からの避難に関する実験的検 
討, 土木学会水工学論文集, 50, 583-588, 2006.

8 ) 原田英治, 後藤仁志, 酒井哲郎, 久保有希; 地下街浸水 時の群衆避難の個体ベースシュミレーション, 土木学会 水工学論文集, 50, 589-594, 2006.

9 ) 東野誠, 高見徹, 中茂義晶, 平島英恵, 井上徹教, 清野
聡子, 高木章次, 荒巻重則, 小松利光 ; 底質環境が河口 干潟の生態系に及ぼす影響一大分県番匠川河口干潟のア サリを対象として一, 土木学会水工学論文集, 48, 13031308, 2004.

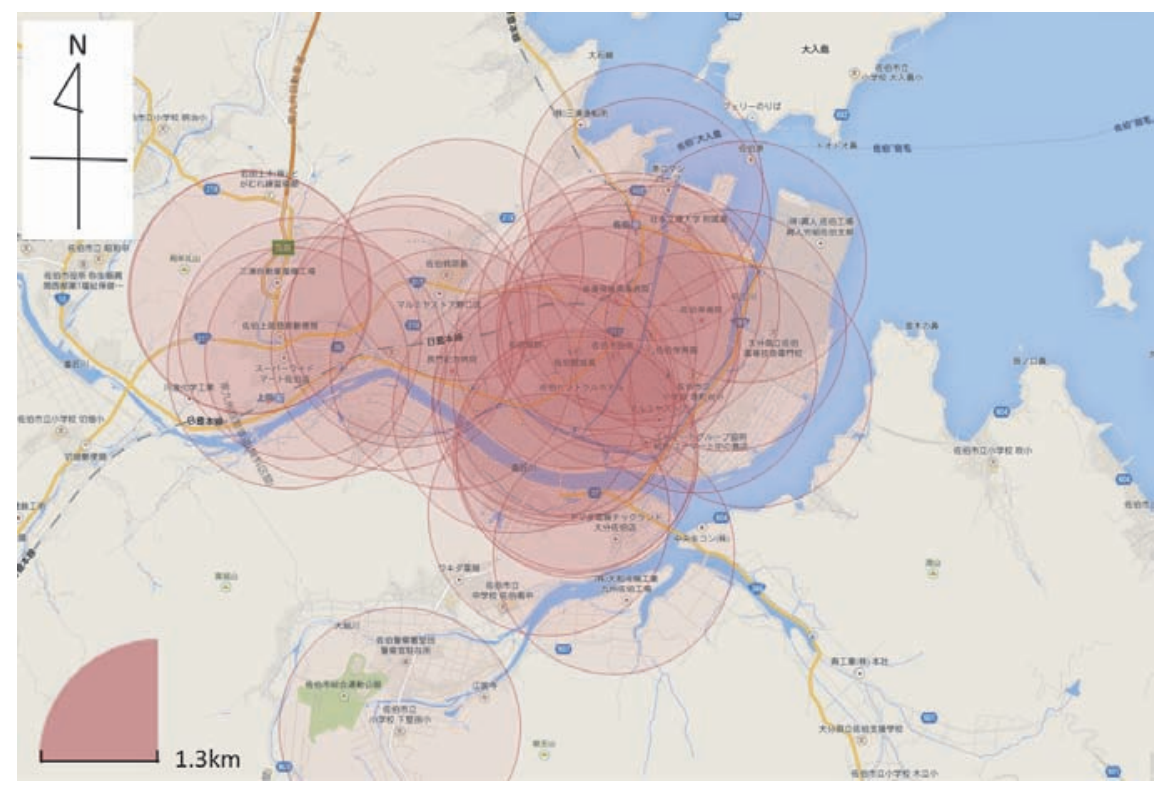

図 6 地震発生時避難可能区域 (緊急避難施設より半径 $1,300 \mathrm{~m}$ )

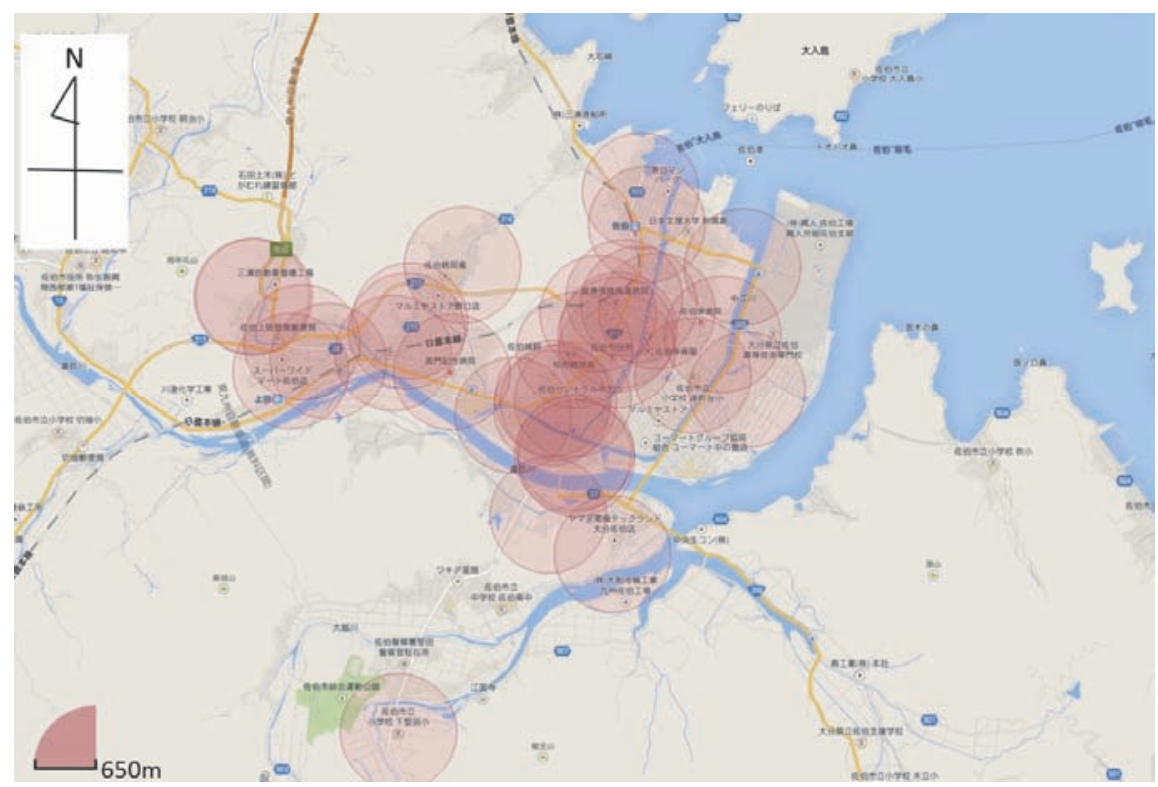

図 7 地震発生時避難可能区域（緊急避難施設より半径 $650 \mathrm{~m} ）$ 